\title{
Students' perceptions toward vocational education on online learning during the COVID-19 pandemic
}

\author{
Khusni Syauqi, Sudji Munadi, Mochamad Bruri Triyono \\ Department of Technology and Vocational Education, Yogyakarta State University, Indonesia
}

\begin{abstract}
Article Info
Article history:

Received May 29, 2020

Revised Sep 6, 2020

Accepted Oct 16, 2020

\section{Keywords:}

COVID-19 pandemic

Online learning

Perception

Vocational education

ABSTRACT

The impact of the Covid-19 pandemic has spread almost throughout the world. It makes all educational institutions in Indonesia experienced a lockdown in an undetermined time. As a result, teachers must switch to online teaching methods, while students must adapt to the online learning environment in a short time. Vocational education emphasizes not only the mastery of knowledge but also skills. In the learning process, students' perceptions can be used as evaluations to improve the quality of learning. This study aimed to provide an overview of students' perceptions of Mechanical Engineering Education on online learning as a result of the impact of the Covid-19 pandemic. This study used survey methods and data collection in the form of instruments with a Likert scale with a sample of 56 students. The results of this study indicate that teachers in managing online learning are not in line with student expectations. Students feel that online learning has not provided better experience and productivity in mastering competencies, but can provide motivation and ease in their learning. Some students stated that they had the ease of access to resources, but students were still reluctant to use it sustainably in the future.
\end{abstract}

This is an open access article under the CC BY-SA license.

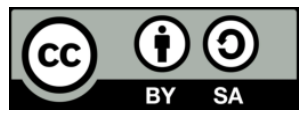

\section{Corresponding Author:}

Khusni Syauqi,

Department of Technology and Vocational Education,

Yogyakarta State University,

Colombo Road No.1, Karangmalang, Yogyakarta, Indonesia.

Email: khusnisyauqi@uny.ac.id

\section{INTRODUCTION}

Educational institutions are currently running abnormally in the presence of Covid-19, which has hit almost every country. Many countries have ordered lockdowns, including the closure of all educational institutions for an indefinite period of time. Face-to-face learning activities in the classroom have been stopped to prevent Covid-19 from spreading and transmitting. As an alternative, the government ordered the learning process in the classroom to be done at home or learning from home. The impact of Covid-19 has triggered all teachers and students to turn to online learning models.

Mechanical engineering education at Yogyakarta State University has made the transition to an online learning environment after the decision of the local government to impose a lockdown. Physical distancing is implemented in the campus environment as a security measure in preventing the spread of Covid-19, and interaction between students and lecturers can only be done in a digital space. However, a significant concern in online learning is about the fulfillment of the number of meetings and not on the quality of content designed. Moreover, the proportion of learning curricula in mechanical engineering education places more emphasis on the aspects of mastery of skills. 
Online learning has become a teaching and learning trend at all levels of education by the end of the decade. Online learning allows teachers and students to change the way learning, and delivery of information varies greatly. Wentling et al. define online learning as the acquisition and use of knowledge distributed and facilitated primarily by electronic means [1]. The form of online learning depends on the network (e.g., wireless, satellite) and the technology (e.g., computer, laptop, smartphone) used. Online learning can take the form of courses and modules and smaller learning objects [2]. Online learning is where content is done online in real-time, and students can participate in courses from anywhere [3,4]. The advantage of using online learning is the flexibility of time and place on various platforms.

Online learning has been recognized as an effective way to improve the quality of teaching and to learn in vocational schools because of its variations in increasing student motivation, satisfaction, and interaction [5,6]. Online learning helps students to learn with speed and comfort according to their own volition [7]. Online learning can be an effective way for students to explore more knowledge of what they can get from classrooms [8]. Also, online learning can provide more control and reducing the cost of completing learning activities that benefit students $[9,10]$. However, learning strategies need to be applied so that student participants have the skills and competencies required for their future careers [11].

The learning process in vocational schools emphasizes that students have skills and competencies through the development of the world of work [12, 13]. Therefore, the domain of the learning process, especially in vocational education, must include cognitive (knowledge), psychomotor (skills), and affective (attitude). Analysis in online learning with questionnaires is needed to have a better understanding of student learning styles and comfort in online learning [14]. The effectiveness of online learning depends on how the content is designed to overcome and understand the obstacles faced by students [15]. Online learning requires a lot of resources and careful planning to achieve learning objectives [7].

The impact of the Covid-19 pandemic on Mechanical Engineering Education for lecturers was required to design online learning in a relatively short amount of time regardless of the course, while students were forced to change their way of learning. On the other hand, not all lecturers have the expertise to design and are familiar with online learning. Ferreira, et al. explain that a teacher must be able to explore and use all technologies related to the learning process [4].

Therefore, this study examines how students' perceptions of Mechanical Engineering Education about online learning during the Covid-19 pandemic. The main aspects of this research are about how students 'perceptions about the quality of online learning that are designed and run, ease of access, and students' perceptions about the continued use of the consequences of the Covid-19 pandemic. Dimensions of essential factors in online learning are based on theories, as shown in Table 1.

Table 1. Summary of operational dimensions used in the study

\begin{tabular}{cl}
\hline Dimension & \multicolumn{1}{c}{ Definitions } \\
\hline Teacher & $\begin{array}{l}\text { Refer to how teachers in mentoring, give a response, feedback, discussion, and clear information [16-18]. } \\
\text { Refer to how online learning increase in better knowledge, better performance and productivity, better } \\
\text { learning, and make it easy to learn [19, 20]. } \\
\text { Refers to how online learning is easy to understand and learn, the material is not too difficult or not too } \\
\text { Instructional Material } \\
\text { easy, feel motivated to do assignments and study material, enough time to study the content, in line with } \\
\text { expectations, and material presented in language that is easy to understand [18, 20, 21]. } \\
\text { Refers to how online learning is can be accessed with various devices, can be accessed cheaply, can be } \\
\text { accessed in multiple places and times, can be accessed with the user's hardware and software, easily get } \\
\text { an internet network to access, and institutional support [20, 22]. } \\
\text { Refers to how online learning feels comfortable, used continuously in the future, feeling happy, and } \\
\text { create enthusiasm and be motivated in learning [21, 23,24]. }\end{array}$ \\
\hline
\end{tabular}

This research is important due to a sudden and massive shift in the use of online learning that has never happened before, especially in the field of Mechanical Engineering Education. The institution does not have enough time to design and plan online learning. The length of the Covid-19 pandemic may create a new learning style civilization for teachers and students in the future. The results of this study can be used as essential input in determining effective online learning seen from students' perceptions.

\section{RESEARCH METHOD}

This study used survey methods and questionnaire instruments to collect data. This research was conducted in the Department of Mechanical Engineering Education, Yogyakarta State University. The questionnaire was distributed online using Google form to 58 students (seven females and 51 males) of Mechanical Engineering Education. The survey instrument was compiled based on the study of existing 
theories and then validated by expert judgment. The instrument was developed with a total of 27 questions using a Likert scale with four alternative answers, namely: 1 (strongly disagree), 2 (disagree), 3 (agree), and 4 (strongly agree). The Likert scale used to measure attitudes, opinions, and perceptions of events or social phenomena [25].

This study uses quantitative descriptive analysis with bar graphs to test the outcome data of student assessments related to feedback in online learning during the Covid-19 pandemic. Descriptive analysis is a way to review or explain the collected data as it is $[25,26]$. Data results of student feedback form then calculate the mean, standard deviation, and percentages to describe in a format that is easy to read and understand. Also, the results of data analysis were interpreted based on the level of relationship using correlation Pearson Product Moment with a t-table value of $0.266(n=58)$ and a significance level of $0.5 \%$.

\section{RESULTS AND DISCUSSION}

Students are asked to provide feedback about their experiences in online learning during the Covid19 pandemic. The results of the student responses were then analyzed descriptively with the help of the SPSS 25 software. The description of the data presented is the total score of each dimension, which includes the maximum score, maximum score, mean and standard deviation, as shown in Table 2.

Table 2. Descriptive statistics of student perceptions in online learning

\begin{tabular}{cccccc}
\hline Dimension & $\mathrm{n}$ & Minimum & Maximum & Mean & Standard Deviation \\
\hline Teacher & 58 & 11 & 21 & 15.59 & 2.193 \\
Knowledge Transfer & 58 & 5 & 16 & 11.66 & 2.417 \\
Instructional Material & 58 & 8 & 21 & 14.60 & 2.778 \\
Access to Resourcess & 58 & 10 & 23 & 15.90 & 2.620 \\
Continue Using & 58 & 4 & 12 & 8.45 & 2.002 \\
\hline
\end{tabular}

Table 2 reveals that the teacher dimensions range from 11 to 21 , with an average of 15.59 and a standard deviation of 2.193. Knowledge transfers range from 5 to 16, with an average of 11.66 and a standard deviation of 2.417. Instructional materials range from 8 to 16, with an average of 14.60 and a standard deviation of 2.778. Access to resources ranges from 10 to 23 , with an average of 15.90 and a standard deviation of 2.620. Finally, continue using ranges from 4 to 12 with an average of 8.45 and a standard deviation of 2.002. Data on the frequency distribution results obtained from student responses are then recapitulated based on the total score of the alternative answers and presented, as shown in Figure 1.

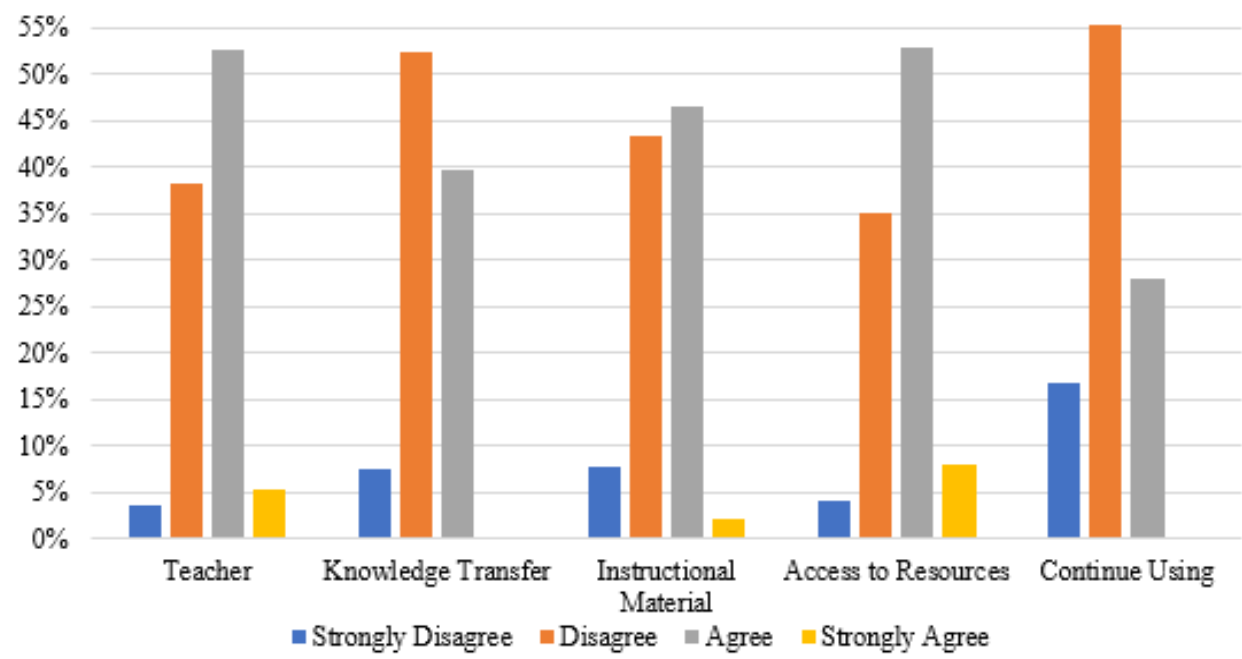

Figure 1. Frequency of student perceptions in online learning

In the first part, the students' perception about the teacher in providing mentoring, response, feedback, discussion, and clear information in online learning is asssesed. The result reveals that $52.59 \%$ of students answered agree, and $38.22 \%$ said they did not agree. This data indicates that the teacher in managing

Students' perceptions toward vocational education on online learning during the ... (Khusni Syauqi) 
online learning is still not in line with student expectations. These authors suggested that this was because some of the teachers were not yet familiar with online learning, for example: how to provide initial learning information, design discussion rooms, and provide feedback with students. Teachers must use technology in a way to support the curriculum rather than master it [27]. Following what Chen and Lu said that some teachers find it challenging to choose the right learning model [14]. In the online learning process, teachers need to understand student feedback about the learning part [28]. Especially that interactive activities between teachers and students will have an impact on student learning outcomes in the process of learning activities [29].

In the second part, regarding students' perceptions of how their experience in gaining knowledge in online learning is seen from aspects of the increase in better knowledge, better performance and productivity, better learning, and make it easy to learn. The result shows that $52.43 \%$ of respondents answered disagree, and $39.58 \%$ stated agreed. This data indicates that students' experiences in online learning as an alternative learning model have not had an effective effect of increasing their knowledge. This finding is not following the opinion of Kisanjara et al. that e-learning useful in increasing knowledge and skills for effectiveness, productivity in their learning, and accomplishing their course tasks quickly [2]. These authors also suggest that part of the learning curriculum in Mechanical Engineering Education places more emphasis on mastering skills than on soft skills. Besides, the teacher in designing and planning to learn is still not following the objectives to be achieved. These findings are due to the short time to design and plan online learning. According to Cakrawati, teacher must be able to integrate technology with content and pedagogy [30].

In the third part, regarding students' perceptions of how instructional material is viewed from aspects of easy to understand and learn, the content is not too difficult or not too easy, feel motivated to do assignments and study material, enough time to study the content, in line with expectations, and material presented in language that is easy to understand. The results showed that $46.66 \%$ of respondents answered they agree, but $43.39 \%$ explained disagreed. These findings indicate that student learning materials that are designed and arranged are still not in line with student expectations. Especially in vocational schools that emphasize mastery of skills by their fields. According to Al-alak and Alnawas that students who have a positive attitude towards technology will have a higher acceptance of the use of technology [23]. Moreover, students are interested in learning that provides various formats such as the use of video, audio, or other technologies that are designed to be more exciting and allow students to respond efficiently [31]. The quality of the material is an essential determinant because it has a positive impact and student satisfaction [20, 32]. Also, students need different attributes such as knowledge about technology use, time management and organization, and interactions using online technology [9].

In the fourth part, regarding students' perceptions of how to get access to resources viewed from aspects accessed with various devices, can be accessed cheaply, can be accessed in multiple places and times, can be accessed with the user's hardware and software, easily get an internet network to access, and institutional support. The results show that $52.87 \%$ of respondents answered they agree, and $35.06 \%$ disagree. These findings indicate that students have not had significant difficulties accessing online learning. These authors suggest that students already feel they have no obstacles in online learning because they are easily accessed by the devices they have and easily accessible. The use of online learning resources enables students to create learning environments that are most suitable for their learning needs and styles [33]. As explained by Muthuprasad, online classes will be successful only if the internet facility is provided to all by making it equitable and affordable [15].

In the fifth part, students' perceptions about how to continue using in online learning viewed from the aspects of feeling comfortable, being used continuously in the future, feeling happy, and creating enthusiasm and being motivated in learning. The results show that $55.17 \%$ of respondents answered they disagree, and $28.02 \%$ agreed. These findings indicate that students feel uncomfortable and happy with the online learning that is followed. These authors suggest that if students often feel online learning can increase knowledge, find it easy to use, and are quick to complete assignments, they will experience a satisfaction. According to Aparicio, that satisfaction can have an impact on student behavior for sustainable use [32]. The use of technology should result in better achievement in student learning so that they will continue to use online learning platforms [34].

Table 3 shows the dimensions of the teacher, knowledge transfer, and instructional material, having a very strong relationship in online learning. These results contradict the results of previous studies of instructors, knowledge transfer, and instructor material able to improve the quality of online learning for students [35]. While access to resources has a strong enough relationship and continues to use, it has a strong relationship in online learning. Overall, this discusses five dimensions related to critical learning and can be made as a reference to factors in online learning. 
Table 3. Level of the interrelationship between dimensions

\begin{tabular}{cccccccc}
\hline Dimension & Teacher & $\begin{array}{c}\text { Knowledge } \\
\text { Transfer }\end{array}$ & $\begin{array}{c}\text { Instructional } \\
\text { Material }\end{array}$ & $\begin{array}{c}\text { Access to } \\
\text { Resources }\end{array}$ & $\begin{array}{c}\text { Continue } \\
\text { Using }\end{array}$ & Total & Level \\
\hline $\begin{array}{c}\text { Teacher } \\
\text { Knowledge } \\
\text { Transfer }\end{array}$ & 1 & $.625^{* *}$ & $.716^{* *}$ & $.264^{*}$ & $.607^{* *}$ & $.811^{* *}$ & Very strong \\
$\begin{array}{c}\text { Instructional } \\
\text { Material }\end{array}$ & 1 & $.562^{* *}$ & $.332^{*}$ & $.667^{* *}$ & $.817^{* *}$ & Very strong \\
$\begin{array}{c}\text { Access to } \\
\begin{array}{l}\text { Resources } \\
\text { Continue } \\
\text { Using }\end{array}\end{array}$ & & 1 & $.375^{* *}$ & $.582^{* *}$ & $.850^{* *}$ & Very strong \\
\hline
\end{tabular}

** Correlation is significant at the 0.01 level (2-tailed).

* Correlation is significant at the 0.05 level (2-tailed).

Online learning during the Covid-19 pandemic is illustrating the importance of the readiness of educational institutions to plan and implement learning. Based on the results of previous studies, to improve the quality of online learning requires the ability to use technology by adjusting teaching methods, discussions, designing teaching materials, and providing feedback for students online [16, 17]. Educational institutions need training for teachers on how to improve online learning, make good material, and make learning media more interactive.

\section{CONCLUSION}

Based on the responses of students in Mechanical Engineering Education, the majority of them feel that online learning is still considered less effective and in line with their expectations. This is evidenced by the magnitude of students' responses that stated disagree. Evaluation of improvement and careful preparation of both teachers and institutions for online learning is needed to be truly effective. The improvement is by increasing the teacher's ability to manage learning, learning materials, and methods in transferring knowledge to be able to improve students' knowledge, attitudes, and skills.

\section{ACKNOWLEDGEMENT}

This paper is dedicated to the Education Fund Management Institution (LPDP) and Yogyakarta State University who have helped and supported the implementation of this research.

\section{REFERENCES}

[1] Wentling, T., Waight, C., Gallaher, J., Fleur, J., Wang, C., and Kanfer, A., "E-learning: A review of the literature," NCSA, The University of Illinois at Urbana-Champaign, 2000.

[2] Kisanjara, S., Tossy, T., Sife, A., and Msanjila, S., "An integrated model for measuring the impacts of E-learning on students' achievement in developing countries," International Journal of Education and Development using Information and Communication Technology, vol. 13, no. 3, pp. 109-127, 2017.

[3] M. Florence and B. Anthony, "Online learning," In Digital Media for Learning. Springer International Publishing, pp. 111-127, 2019.

[4] Ferreira, J., et al., "The necessary knowledge for online education: teaching and learning to produce knowledge," Eurasia Journal of Mathematics, Science and Technology Education, vol. 14, no. 6, pp. 2097-2106, 2018.

[5] Belaya, V., "The use of e-learning in vocational education and training (VET): Systematization of existing theoretical approaches," Journal of Education and Learning, vol. 7, no. 5, pp. 92-101, 2018.

[6] Bignoux, S. and Sund, K., "Tutoring executives online: What Drives Perceived Quality?" Behaviour and Information Technology, vol. 37, no. 7, pp. 1-11, 2018.

[7] D. Indira and A. Sakshi, "Online learning," International Education \& Research Journal, vol. 3, no. 8, pp. 32-34, 2017.

[8] Harsasi, M., "The use of open educational resources in online learning: A study of students' perception," Turkish Online Journal of Distance Education, vol. 16, no. 3, pp. 74-87, 2015.

[9] T. Joosten and R. Cusatis, "Online learning readiness," American Journal of Distance Education, vol. 34, no. 3, pp. 1-14, 2020.

[10] Cidral, W. A., Oliveira, T., Di Felice, M., and Aparicio, M., "E-learning success determinants: Brazilian empirical study," Computers \& Education, vol. 122, pp. 273-290, Jul. 2018.

[11] Kelz, A., "E-learning strategies in technical part-time studies at Campus Pinkafeld - a moderate constructivist approach to learning and teaching," International Journal of Advanced Corporate Learning, vol. 2, no. 1, pp. 25-30, 2009.

[12] Widiatna, A.D., Teaching Factory: A new direction for vocational high school management in Indonesia (in Bahasa), Jakarta Timur: Pustaka Aji, 2019.

Students' perceptions toward vocational education on online learning during the ... (Khusni Syauqi) 
[13] Clark, L. and Winch, C., Vocational education international approaches, development and systems, New York: Routledge, 2007.

[14] Chen, S. and Lu, Y., "The negative effects and control of blended learning in university," International Conference on Education Technology and Information System, Atlantis Press, pp. 28-31, 2013.

[15] Muthuprasad, T., Aiswarya, S., Aditya, K.S., and Jha, G.K., "Students' perception and preference for online education in India DURING Covid-19 Pandemic," Journal of First Look Social Sciences and Humanities Open, 2020. [Online]. Available: http://dx.doi.org/10.2139/ssrn.3596056

[16] Gulbahar, Y. and Kalelioglu, F., "Competencies for E-instructors: How to qualify and guarantee sustainability," Contemporary Educational Technology, vol. 6, no. 2, pp. 140-154, 2015.

[17] Lin, C. and Zheng, B., "Teaching practices and teacher perceptions in online world language courses," Journal of Online Learning Research, vol. 1, no. 3, pp. 275-304, 2015.

[18] Caicedo, J.E., Berrío, S.P., and Pinzón, O.J., "Service quality for continuing higher education in online learning environments," Entramado, vol. 14, no. 2, pp. 22-34, 2018.

[19] Hansen, D.E., "Knowledge transfer in online learning environments," Journal of Marketing Education, vol. 30, no. 2, pp. 93-105, 2008.

[20] Sun, P., Tsai, R.J., F.G., Chen, Y.Y., and Yeh, D., "What drives a successful e-learning? An empirical investigation of the critical factors influencing learner satisfaction," Computers and Education, vol. 50, no. 4, pp. 1183-1202, 2008.

[21] Lin, K.M., "E-learning continuance intention: Moderating effects of user E-learning experience," Computers and Education, vol. 56, no. 2, pp. 515-526, 2010.

[22] Bisset, J.A., "The move to modern learning environments in New Zealand secondary schools: Step forward or smokescreen?" Thesis, Unitec Institute of Technology, 2014.

[23] Al-alak, B. and Alnawas, I., "Measuring the Acceptance and Adoption of E-learning by Academic Staff," Knowledge Management and E-Learning: An International Journal, vol. 3, no. 2, pp. 201-221, 2011.

[24] Salloum, S. and Shaalan, K., "Factors affecting students' acceptance of E-learning system in higher education using UTAUT and structural equation modeling approaches," Book Chapter: Proceedings of the International Conference on Advanced Intelligent Systems and Informatics, Springer International Publishing, pp. 469-480, 2019.

[25] Riduwan and Sunarto, Introduction to statistics for research: Educational, social, economic and business (in Bahasa), Bandung: Alfabeta, p. 20, 2007.

[26] Purwanto, A., Inferential statistics lab guide (in Bahasa), Jakarta: Grasindo, 2007.

[27] Zolfaghari, V., and Kargozari, M., "Influences of Digital Classrooms on Education," Procedia CS, vol. 3, pp. 1178-1183, 2011.

[28] Nguyen, V. A., "The impact of online learning activities on student learning outcome in blended learning course," Journal of Information \& Knowledge Management, vol. 16, no. 4, 2017.

[29] Kang, M. and Im, T., "Factors of learner instructor interaction which predict perceived learning outcomes in online learning environment," Journal of Computer Assisted Learning, vol. 29, no. 3, pp. 292-301, 2013.

[30] Cakrawati, L. M., "Students' Perceptions on The Use of Online Learning Platforms in EFL Classroom," Journal of English Language Teaching and Technology, vol. 1, no. 1, pp. 22-30, 2017.

[31] Sun, A. and Chen, X., "Online education and its effective practice: A research review," Journal of Information Technology Education: Research, vol. 15, pp. 157-190, 2016.

[32] Aparicio, M., Bacao, F., and Oliveira, T., "Grit in the path to e-learning success," Computers in Human Behavior, vol. 66, pp. 388-399, Jan. 2017.

[33] Lebeničnik, M., Pitt, I., and Istenic, S. A., "Use of online learning resources in the development of learning environments at the intersection of formal and informal learning: The student as autonomous designer," Center for Educational Policy Studies Journal, vol. 5, no. 2, pp. 95-113, 2015.

[34] Lwoga, E. and Komba, M., "Antecedents of continued usage intentions of web-based learning management system in tanzania," Education and Training, vol. 57, no. 7, pp. 738-756, 2015.

[35] Gray, J. and Diloreto, M., "The Effects of Student Engagement, Student Satisfaction, and Perceived Learning in Online Learning Environments," International Journal of Educational Leadership Preparation, vol. 11, no. 1, pp. 89-119, 2016. 